\title{
Age Criteria as Operative Mortality Predictor after Modified Blalock-Taussig Shunt
}

\author{
Muammar Riyandi 1, Oktavia Lilyasari 1,Dafsah Arifa Juzar 1, \\ Indriwanto Sakidjan 1, Radityo Prakoso 1, Budi Rahmat2
}

\begin{abstract}
Background: Modified Blalock-Taussig shunt (MBTS) is considered as a simple procedure but has a considerable operative mortality rate. Patient's characteristics who underwent MBTS in Indonesia is quite different than other country. There was no predictor of operative mortality has been identified in Indonesian. To compare mortality rate based on age criteria and to identify mortality and morbidity predictors after MBTS procedure. Methods: A retrospectively cohort study was conducted on 400 patients who underwent MBTS at National cardiovascular center Harapan Kita (NCCHK) between January 2013 and december 2017.

Results: There were 32,1\% death at age $\leq 28$ days, $19,9 \%$ at age $29-365$ days, 3,6\% at age 366-I825 days and $8 \%$ at age $>1825$ days. Body weight $<3 \mathrm{~kg}$, haematocrite level $>45 \%$ before procedure and activated partial thromboplastine time level (aPTT) $<60$ seconds were operative mortality predictors. Postoperative morbidity rate was 32,9\%. Packed red cell transfusion (PRC) more than $6 \mathrm{ml} / \mathrm{kg}$, mechanical ventilator use before procedure, prostaglandin EI use before procedure, aPTT level less than 60 seconds after procedure were identified as postoperative morbidity predictors.

Conclusion: Operative mortality rate significantly different among age criteria but it was not proven as an operative mortality predictors. Body weight $<3 \mathrm{~kg}$ increase mortality rate and haematocrite level higher than $45 \%$ and aPTT level less than 60 seconds decrease mortality rate. Postoperative morbidity predictors were PRC transfusion more than $6 \mathrm{ml} / \mathrm{kg}$, mechanical ventilator use before procedure, prostaglandine EI use and aPTT level less than 60 seconds.
\end{abstract}

Keywords: Age Criteria, Blalock-Taussig Shunt, Morbidity, Mortality

(Indonesian J Cardiol. 2019;40:216-22I)

I Department of Pediatric Cardiology and Congenital Heart Disease, Faculty of Medicine Universitas Indonesia-National Cardiovascular Center Harapan Kita

2 Department of Pediatric Cardiology and Congenital Heart Disease, Faculty of Medicine Universitas Indonesia-National Cardiovascular Center Harapan Kita

\section{Correspondence:}

dr. Dafsah Arifa Juzar, Sp.JP (K)

Department of Pediatric Cardiology and Congenital Heart Disease, Faculty of Medicine Universitas Indonesia-National Cardiovascular Center Harapan Kita

E-mail: djuzar@gmail.com

\section{Introduction}

he modified Blalock-Taussig shunt (MBTS)
is commonly performed to deliver a reliable
source of pulmonary blood flow in neonates
born with complex congenital heart defects associated with pulmonary stenosis or atresia. ${ }^{(1)}$ In spite of being a small operation, MBTS is associated with significant mortality risk of around $7-9 \% .{ }^{(2)}$ Bove et al., found out that the outcome of palliation with the MBTS is importantly affected by the occurrence of a 
Indonesian Journal of Cardiology

Table 1. Outcome of modified Blalock-Taussig shunt

\begin{tabular}{lccccc}
\hline \multicolumn{1}{c}{ Variable } & $\begin{array}{c}<2 \text { days } \\
(\mathrm{n}=28)\end{array}$ & $\begin{array}{c}29-365 \\
(\mathrm{n}=146)\end{array}$ & $\begin{array}{c}366-1825 \\
(\mathrm{n}=138)\end{array}$ & $\begin{array}{c}>1825 \\
(\mathrm{n}=88)\end{array}$ & $\mathrm{p}$-value \\
\hline Mortality & $9(32,1 \%)$ & $29(19,9 \%)$ & $5(3,6 \%)$ & $7(8 \%)$ & $<0,001$ \\
Morbidity & $17(63 \%)$ & $59(40,7 \%)$ & $32(23,2 \%)$ & $23(26,7 \%)$ & $<0,001$ \\
Bleeding & $11(39,3 \%)$ & $47(32,4 \%)$ & $25(18,1 \%)$ & $17(19,3 \%)$ & 0,006 \\
Sepsis & $5(18,5 \%)$ & $14(9,8 \%)$ & $2(1,4 \%)$ & $1(1,1 \%)$ & $<0,001$ \\
Redo MBTS & $4(14,8 \%)$ & $3(2,1 \%)$ & $9(6,5 \%)$ & $9(10,2 \%)$ & 0,019 \\
ICU > 48 jam & $23(85,2 \%)$ & $97(67,4 \%)$ & $50(36,2 \%)$ & $36(51,9 \%)$ & $<0,001$ \\
\hline
\end{tabular}

a median (minimum-maksimum)

shunt-related complication. (3) Several shunt related complication has identified, such as shunt occlusion, shunt overcirculation that can increase mortality and manifest as congestive heart failure and necrotizing enterocolitis. ${ }^{(2)}$

The resources to treat congenital heart disease are both inadequate and seriously maldistributed. The 2007-2009 World Society for Paediatric Heart Surgery Manpower Survey noted that about 75\% of the world's population have no access to cardiac surgery, and that the distribution of cardiac surgeons was very unbalanced. This is in keeping with the variation in distribution of cardiovascular centres. This is often compounded by limited education of the population in the developed nations. ${ }^{(4)}$

In Indonesia, because of those limitation, the patient who underwent Blalock-Taussig shunt came to hospital in older age. Based on data from 20162017 in National Cardiovascular Center Harapan Kita (NCCHK), overall mortality was $13,5 \%$ with $1,5 \%$, $41 \%$ and $57,5 \%$ population proportion underwent BTS were neonates, infants and older children or aldult respectively. It is noted that, there were $11 \%$ proportion older than 10 years old. Because of the different population characteristics and higher mortality than other study, it is important to identify the predictors of mortality in Indonesia.

\section{Methods}

Data were retrospectively collected from clinical records of all patients undergoing an MBTS at NCCHK, from January 2013 to December 2017. Approval of the ethical committee of the NCCHK was obtained for this study, and informed consent was waived for its retrospective design. Inclusion criteria was all MBTS procedure and any concomitant procedure other than surgical closure of patent ductus arteriosus (PDA) and major aortopulmonary collateral arteries (MAPCAs), pulmonary artery repair and atrial septectomy were grounds for exclusion.

The primary end point was operative mortality. The secondary end point was composite morbidity. Composite morbidity was defined as occurrence of any one or more of the following: postoperative bleeding, reoperation, sepsis and intensive care unit (ICU) stay unit more than 48 hours. Patient's preoperative characteristics included in the analysis were age, gender, body weight, diagnosis, haemoglobin and haematocrite level, genetic syndrome, mechanical ventilator use and prostaglandine use. Intraoperative characteristics were aortic cross clamp (AoX) and cardiopulmonary bypass (CPB) use, sternotomi approach, graft diameter, competitive flow, pulmonary repair and atrial septectomy. Postoperative characteristics including haemoglobin, haematocrite and activated partial thromboplastine time (aPTT) level. Age was divided into four categories, age under 28 days, 29-365 days, 366-1825 days and age more than 1825 days. Haemoglobin level divided into $15 \%$ and more and under $15 \%$. Haematocrite level will be categorized into $45 \%$ and more and less than $45 \%$.

\section{Statistical Analysis}

Statistical analysis was performed with SPSS software Statistics 20 (IBM, SPSS, Inc., Chicago, Illinois). Normality of data distribution was assessed by Kolmogorov-Smirnov test. Categorical variables are expressed as number and percentage, and comparisons are done using chi-square or Fisher exact test. Continuous variables are presented as mean + standard deviation or as median and interquartile range, 
Indonesian Journal of Cardiology

Table 2. Univariate Analysis for predictors of mortality and morbidity

\begin{tabular}{|c|c|c|c|c|c|c|c|}
\hline \multirow{2}{*}{\multicolumn{2}{|c|}{ Variable }} & \multicolumn{2}{|c|}{ Mortality } & \multirow{2}{*}{ p-value } & \multicolumn{2}{|c|}{ Morbidity } & \multirow{2}{*}{$\mathrm{p}$-value } \\
\hline & & Yes & No & & Yes & No & \\
\hline Age & $\begin{array}{c}\leq 28 \text { days } \\
29-365 \text { days } \\
366-1825 \text { days } \\
>1825 \text { days }\end{array}$ & $\begin{array}{c}9(18 \%) \\
29(58 \%) \\
5(10 \%) \\
7(14 \%)\end{array}$ & $\begin{array}{c}19(5,4 \%) \\
117(33,4 \%) \\
133(38 \%) \\
81(23,1 \%)\end{array}$ & $0,004^{\mathrm{b}}$ & $\begin{array}{c}26(10,6 \%) \\
114(46,5 \%) \\
63(25,7 \%) \\
42(17,1 \%)\end{array}$ & $\begin{array}{c}1(0,7 \%) \\
31(20,3 \%) \\
75(49 \%) \\
46(30,1 \%)\end{array}$ & $<0,001^{\mathrm{a}}$ \\
\hline Body weight & $\begin{array}{l}<3 \mathrm{~kg} \\
\geq 3 \mathrm{~kg}\end{array}$ & $\begin{array}{c}11(22 \%) \\
39(10,5 \%)\end{array}$ & $\begin{array}{c}14(4,1 \%) \\
333(89,5 \%)\end{array}$ & $<0,001^{b}$ & $\begin{array}{c}20(8,2 \%) \\
223(91,8 \%)\end{array}$ & $\begin{array}{c}5(3,3 \%) \\
147(96,7 \%)\end{array}$ & $0,05^{\mathrm{a}}$ \\
\hline Ventilator & $\begin{array}{l}\text { Yes } \\
\text { No }\end{array}$ & $\begin{array}{c}15(30 \%) \\
35(10,2 \%)\end{array}$ & $\begin{array}{c}41(11,7 \%) \\
309(89,8 \%)\end{array}$ & $<0,001^{\mathrm{a}}$ & $\begin{array}{c}50(20,4 \%) \\
195(79,6 \%)\end{array}$ & $\begin{array}{c}5(3,3 \%) \\
148(96,7 \%)\end{array}$ & $<0,001^{\mathrm{a}}$ \\
\hline Prostaglandin & $\begin{array}{l}\text { Yes } \\
\text { No }\end{array}$ & $\begin{array}{l}18(36 \%) \\
32(9,6 \%)\end{array}$ & $\begin{array}{c}49(14 \%) \\
301(90,4 \%)\end{array}$ & $<0,001^{\mathrm{a}}$ & $\begin{array}{c}61(24,9 \%) \\
184(75,1 \%)\end{array}$ & $\begin{array}{c}4(2,6 \%) \\
149(97,4 \%)\end{array}$ & $<0,001^{\mathrm{a}}$ \\
\hline $\mathrm{Hb}$ (pre) & $\begin{array}{l}\mathrm{Hb}>15 \mathrm{~g} / \mathrm{dl} \\
\mathrm{Hb} \leq 15 \mathrm{~g} / \mathrm{dl}\end{array}$ & $\begin{array}{c}23(46 \%) \\
27(20,6 \%)\end{array}$ & $\begin{array}{l}246(70,3 \%) \\
104(79,4 \%)\end{array}$ & $0,001^{\mathrm{a}}$ & $\begin{array}{l}142(58 \%) \\
103(42 \%)\end{array}$ & $\begin{array}{c}127(83 \%) \\
26(17 \%)\end{array}$ & $<0,001^{\mathrm{a}}$ \\
\hline Ht (pre) & $\begin{array}{l}\mathrm{Ht}>45 \% \\
\mathrm{Ht} \leq 45 \%\end{array}$ & $\begin{array}{c}21(42 \%) \\
29(25,9 \%)\end{array}$ & $\begin{array}{c}267(76,3 \%) \\
83(74,1 \%)\end{array}$ & $<0,001^{\mathrm{a}}$ & $\begin{array}{c}156(63,7 \%) \\
89(36,3 \%)\end{array}$ & $\begin{array}{c}132(86,3 \%) \\
21(13,7 \%)\end{array}$ & $<0,001^{\mathrm{a}}$ \\
\hline Univentrikuler & $\begin{array}{l}\text { Yes } \\
\text { No }\end{array}$ & $\begin{array}{l}21(17,1 \%) \\
29(10,5 \%)\end{array}$ & $\begin{array}{l}102(82,9 \%) \\
248(89,5 \%)\end{array}$ & $0,065^{\mathrm{a}}$ & $\begin{array}{c}83(33,9 \%) \\
162(66,1 \%)\end{array}$ & $\begin{array}{c}39(25,5 \%) \\
114(74,5 \%)\end{array}$ & $0,077^{\mathrm{a}}$ \\
\hline Diagnosis & $\begin{array}{c}\text { PA-IVS } \\
\text { PA-VSD } \\
\text { TOF } \\
\text { PA-CAVSD } \\
\text { Ebstein }\end{array}$ & $\begin{array}{c}12(24 \%) \\
20(40 \%) \\
7(14 \%) \\
3(6 \%) \\
1(2 \%)\end{array}$ & $\begin{array}{c}32(9,1 \%) \\
128(36,6 \%) \\
114(32,6 \%) \\
10(2,9 \%) \\
1(0,3 \%)\end{array}$ & $0,235^{\mathrm{b}}$ & $\begin{array}{c}36(14,7 \%) \\
97(39,6 \%) \\
55(22,4 \%) \\
10(4,1 \%) \\
2(0,8 \%)\end{array}$ & $\begin{array}{c}7(4,6 \%) \\
50(32,7 \%) \\
66(43,1 \%) \\
3(2,0 \%) \\
-\end{array}$ & $0,526^{\mathrm{b}}$ \\
\hline Competitive flow & $\begin{array}{l}\text { Yes } \\
\text { No }\end{array}$ & $\begin{array}{c}13(26 \%) \\
37(13,6 \%)\end{array}$ & $\begin{array}{l}114(32,6 \%) \\
236(86,4 \%)\end{array}$ & $0,418^{\mathrm{a}}$ & $82(33,5 \%)$ & $45(29,4 \%)$ & $0,398^{\mathrm{a}}$ \\
\hline Sternotomi & $\begin{array}{l}\text { Yes } \\
\text { No }\end{array}$ & $\begin{array}{l}47(94 \%) \\
3(2,2 \%)\end{array}$ & $\begin{array}{l}216(61,7 \%) \\
134(97,8 \%)\end{array}$ & $<0,001^{\mathrm{a}}$ & $\begin{array}{c}186(71,3 \%) \\
59(24,1 \%)\end{array}$ & $\begin{array}{c}75(28,7 \%) \\
78(51 \%)\end{array}$ & $<0,001^{\mathrm{a}}$ \\
\hline Transfusi & $\begin{array}{l}\text { Yes } \\
\text { No }\end{array}$ & $\begin{array}{l}17(34,7 \%) \\
32(10,9 \%)\end{array}$ & $\begin{array}{c}88(25,1 \%) \\
262(89,1 \%)\end{array}$ & $0,155^{\mathrm{a}}$ & $\begin{array}{c}99(40,4 \%) \\
146(59,6 \%)\end{array}$ & $\begin{array}{c}6(3,9 \%) \\
147(96,1 \%)\end{array}$ & $<0,001^{\mathrm{a}}$ \\
\hline $\mathrm{Hb}$ (post) & $\begin{array}{l}>14 \mathrm{~g} / \mathrm{dl} \\
\leq 14 \mathrm{~g} / \mathrm{dl}\end{array}$ & $\begin{array}{l}22(47,8 \%) \\
24(16,1 \%)\end{array}$ & $\begin{array}{l}225(64,3 \%) \\
125(83,9 \%)\end{array}$ & $0,03^{\mathrm{a}}$ & $\begin{array}{l}128(52,5 \%) \\
116(47,5 \%)\end{array}$ & $\begin{array}{c}119(78,3 \%) \\
33(21,7 \%)\end{array}$ & $<0,001^{\mathrm{a}}$ \\
\hline $\mathrm{Ht}$ (post) & $\begin{array}{l}>45 \% \\
\leq 45 \%\end{array}$ & $\begin{array}{l}17(37 \%) \\
29(63 \%)\end{array}$ & $\begin{array}{l}214(61,1 \%) \\
136(38,9 \%)\end{array}$ & $0,002^{\mathrm{a}}$ & $\begin{array}{l}120(49,2 \%) \\
124(50,8 \%)\end{array}$ & $\begin{array}{l}111(73 \%) \\
41(27 \%)\end{array}$ & $<0,001^{\mathrm{a}}$ \\
\hline aPTT & $\begin{array}{c}\geq 60 s \\
<60 \text { detik }\end{array}$ & $\begin{array}{c}19(47,5 \%) \\
14(35 \%)\end{array}$ & $\begin{array}{c}55(16,3 \%) \\
242(71,8 \%)\end{array}$ & $<0,001^{\mathrm{a}}$ & $\begin{array}{c}59(25,4 \%) \\
141(60,8 \%)\end{array}$ & $\begin{array}{c}15(10,3 \%) \\
115(79,3 \%)\end{array}$ & $<0,001^{\mathrm{a}}$ \\
\hline $\mathrm{CPB}$ & $\begin{array}{l}\text { Yes } \\
\text { No }\end{array}$ & $\begin{array}{c}24(30,8 \%) \\
26(8,1 \%)\end{array}$ & $\begin{array}{c}54(69,2 \%) \\
296(91,9 \%)\end{array}$ & $<0,001^{\mathrm{b}}$ & $\begin{array}{c}55(22,4 \%) \\
190(77,6 \%)\end{array}$ & $\begin{array}{c}22(14,4 \%) \\
131(85,6 \%)\end{array}$ & $0,047^{\mathrm{a}}$ \\
\hline AoX & $\begin{array}{l}\text { Yes } \\
\text { No }\end{array}$ & $\begin{array}{c}14(28 \%) \\
36(10,3 \%)\end{array}$ & $\begin{array}{c}35(10 \%) \\
315(89,7 \%)\end{array}$ & $<0,001^{\mathrm{a}}$ & $\begin{array}{c}36(14,7 \%) \\
209(85,3 \%)\end{array}$ & $\begin{array}{c}12(7,8 \%) \\
141(92,2 \%)\end{array}$ & $0,041^{\mathrm{a}}$ \\
\hline Anastomosis & $\begin{array}{c}\text { Innominata artery-PA } \\
\text { Subclavia-PA } \\
\text { Aorta-PA }\end{array}$ & $\begin{array}{l}36(72 \%) \\
8(16 \%) \\
6(12 \%)\end{array}$ & $\begin{array}{c}195(56 \%) \\
140(40,2 \%) \\
10(2,9 \%)\end{array}$ & $0,032^{\mathrm{a}}$ & $\begin{array}{c}163(66,8 \%) \\
70(28,7 \%) \\
9(3,7 \%)\end{array}$ & $\begin{array}{c}66(43,4 \%) \\
78(51,3 \%) \\
7(4,6 \%)\end{array}$ & $<0,001^{\mathrm{a}}$ \\
\hline Atrial septectomy & $\begin{array}{l}\text { Yes } \\
\text { No }\end{array}$ & $\begin{array}{c}12(24 \%) \\
38(10 \mathrm{~m} 6 \%)\end{array}$ & $\begin{array}{c}30(8,6 \%) \\
320(89,4 \%)\end{array}$ & $0,001^{\mathrm{a}}$ & $\begin{array}{c}33(13,5 \%) \\
212(86,5 \%)\end{array}$ & $\begin{array}{c}8(5,2 \%) \\
145(94,8 \%)\end{array}$ & $0,009^{\mathrm{a}}$ \\
\hline PA repair & $\begin{array}{l}\text { Yes } \\
\text { No }\end{array}$ & $\begin{array}{c}3(6 \%) \\
47(12,1 \%)\end{array}$ & $\begin{array}{c}9(2,6 \%) \\
341(87,8 \%)\end{array}$ & $0,18^{\mathrm{b}}$ & $\begin{array}{c}5(2 \%) \\
240(98 \%)\end{array}$ & $\begin{array}{c}7(4,6 \%) \\
146(95,4 \%)\end{array}$ & $0,226^{\mathrm{b}}$ \\
\hline
\end{tabular}

${ }^{\mathrm{a}} \mathrm{p}$ value using chi square test. ${ }_{\mathrm{p}} \mathrm{p}$ value using Fisher's Exact test. 
Table 3. Multivariate analysis of operative mortality after MBTS

\begin{tabular}{lccc}
\hline \multicolumn{1}{c}{ Variable } & OR & $95 \%$ CI & p-value \\
\hline Age $\leq 28$ days & 0,869 & $0,232-3,251$ & $0,835^{\mathrm{a}}$ \\
Body weight $<3 \mathrm{~kg}$ & 5,876 & $1,872-18,441$ & $0,002^{\mathrm{a}}$ \\
aPTT $<60$ seconds & 0,241 & $0,108-0,536$ & $<0,001^{\mathrm{a}}$ \\
Haematocrite level $>45 \%$ preoperatively & 0,106 & $0,020 \pm 0,579$ & $0,009^{\mathrm{a}}$ \\
\hline
\end{tabular}

${ }^{a} \mathrm{p}$ value is obtained through logistic regression for multivariate analysis

Table 4. Multivariate analysis of morbidity after MBTS

\begin{tabular}{lccc}
\hline \multicolumn{1}{c}{ Variable } & OR & $95 \%$ CI & p-value \\
\hline Age $\leq 28$ days & 4,671 & $0,533-40,920$ & $0,161^{\mathrm{a}}$ \\
PRC transfusion $>6 \mathrm{ml} / \mathrm{kg}$ & 17,048 & $6,608-43,984$ & $<0,001 \mathrm{a}$ \\
Preoperative ventilator & 8,554 & $2,476-29,548$ & $0,001^{\mathrm{a}}$ \\
Prostaglandine E1 use & 6,273 & $2,084-18,881$ & $0,001^{\mathrm{a}}$ \\
aPTT $<$ 60 seconds & 0,434 & $0,248-0,759$ & $0,003^{\mathrm{a}}$ \\
\hline
\end{tabular}

${ }^{a} \mathrm{p}$ value is obtained through logistic regression for multivariate analysis

depending on the normality of their distribution. Comparison of continuous variables are consequently analyzed by unpaired $t$ test or Mann-Whitney test. Analysis of predictors for operative mortality was based on a multivariable stepwise logistic regression model (backward likelihood ratio). Risk factors were identified by the odds ratio (OR) and 95\%confidence interval (CI) estimation. A p value $<.05$ was considered statistically significant.

\section{Results}

A total of 449 patients met the inclusion criteria. Of these, 46 patients with concomitant surgery and 3 patients lost to follow up after discharged were excluded. Finally, 400 patients were included in this study. The median age at operation was 572 days (7-12710 days), with 28 patients $(7 \%)$ younger than 29 days, 146 patients $(36,5 \%)$ at age $29-365$ days, 138 patients $(34,5 \%)$ at age 366-1825 days and 88 patients (22\%) at age more than 1825 days. In this study, overall, 50 patients did not survive after the MBTS (12,5\% mortality) with the highest mortality rate at age younger than 29 days and 29-365 days old. The composite morbidity, as defined, occurred in 131 patients (32,9\%), including 100 patients $(25,1 \%)$ with abnormal bleeding, 22 patients (5,6\%) with sepsis, 25 patients $(6,3 \%)$ with redo MBTS and 206 patients $(51,9 \%)$ with ICU stay more than 48 hours (table 1).

Bivariate statistical analysis was performed on factors affecting MBTS operative mortality and composite morbidity. The variable to be tested is a variable considered to have an effect on the operative mortality of MBTS based on previous research. Table 2 shows bivariate analysis between the independent variables to operative mortality and composite morbidity. We observed that death was significantly increase with weight of less than $3 \mathrm{~kg}$ (OR 5,876, 95\% CI 1,872-18,441; $<<0.05)$, whereas the hematocrit level of preoperative $>45$ (OR 0,106; 95\%CI 0,020,579; $\mathrm{p}<0,05$ ) and APTT $<60$ seconds (OR 0.241; 95\% CI 0.108-0.536; $\mathrm{p}<0.05$ ) will reduce the risk of operative mortality. Neonatal age although it has a role in increasing mortality, but not statistically significant in multivariate analysis. (OR 0.869 ; 95\%CI 0.232 $3.251 ; \mathrm{p}>0.05$ ) (table 3). Factors that were significantly associated with composite morbidity included presence of history of transfusion (OR 17,048, 95\%CI 6,60843,984, p <0,05), mechanical ventilation (OR 8,554; $95 \%$ CI $2,476-29,548, \mathrm{p}<0,05)$, use of prostaglandin (OR 6,273; 95\%CI 2,084-18,881, p <0.05). While APTT levels $<60$ seconds will decrease morbidity (OR $0.434,95 \%$ CI $0.248-0.759, \mathrm{p}<0.05)$ Neonatal age although it has a role in increasing mortality, but not statistically significant in multivariate analysis. (OR 4,671; 95\%CI 0,533-40,920, p> 0,05)(table 4).

\section{Discussion}

Operative mortality after MBTS in this study was obtained in 50 patients $(12.5 \%)$ with the largest proportion in the age group $\leq 28$ days $(32.1 \%)$. This rate is greater than the study by Singh et al that get a number $4,5 \%$ for overall mortality and $8 \%$ for neonates. ${ }^{(5)}$ 
Differences in the characteristics of the samples in both studies may explain the presence of higher mortality differences in our study. In the study of Singh et al, the method used was thoracotomy and the study did not include patients with PA-IVS in their research samples. In this study, sternotomy was performed in $57.4 \%$ of cases and PA-IVS morphology was present in $11 \%$ of the population. Both of these variables were shown to have a significant association to the increase in MBTS operative mortality in bivariate analysis.

In this population, we found that age did not affect mortality rates after the MBTS. Weight less than $3 \mathrm{~kg}$ was known to increase mortality by 5.8 times in this study (OR 5.876, 95\%CI 1,872-18,441; p = 0.002). Another study conducted by Petrucci et al, found that weight less than $3 \mathrm{~kg}$ as a predictor of operative mortality. The mechanism that plays a role is the unavailability of graft smaller than $3 \mathrm{~mm}$ and smaller pulmonary artery size and consequent complications due to the more frequent use of prostaglandins in this population. ${ }^{(6)}$ In this study, in patients with $\mathrm{BB}<3 \mathrm{~kg}$, the MBTS procedure was performed with a sternotomy technique with a proportion of $100 \%$. this approach often leads to excessive shunt flows since the graft is fitted more proximal and tends to use larger sizes thus increasing the risk of overcirculation. ${ }^{(7)}$

Hematocrit levels were greater than $45 \%$ when preoperative decreased mortality by 9 times (OR 0.106 ; $95 \%$ CI $0.020-0.579 ; \mathrm{p}=0.009)$. In this study, in bivariate analysis, hematocrit levels greater than $45 \%$ were associated with fewer bleeding events (OR 0.656; 95\%CI 0.466-0.924, $\mathrm{p}=0.018$ ). Decreased mortality in these circumstances was due to decreased risk of bleeding. Hypovolemia due to bleeding in cyanotic PJB may exacerbate the cyanotic condition due to increase right to left shunt. ${ }^{(8)}$ Decreased blood flow may cause stasis in MBTS and result in thrombosis.

APTT levels $<60$ seconds will decrease mortality by up to 4 times (OR 0.241; IK95\% 0.108-0.536; p $<0.001)$. Based on the literature, the aPTT target to be achieved is $60-90$ seconds. ${ }^{(9)}$ The risk of thrombosis will increase at low levels of aPTT. However, in a study conducted by Kucuk et al, obtained aPTT levels of 34.95 seconds as a predictor of the incidence of thrombosis in MBTS. (10) This lower aPTT level that predicted thrombosis in MBTS suggests that there are different therapeutic targets in different populations. However, in this study, an aPTT analysis of less than 40 seconds was not done due to the limited number of samples.

From a multivariate analysis of postoperative morbidity, a PRC transfusion of more than $6 \mathrm{ml} / \mathrm{kg}$, preoperative use of mechanical ventilation, preoperative use of prostaglandin E1 would increase postoperative morbidity. Meanwhile, an aPTT levels $<60$ seconds at 4 $\mathrm{h}$ postoperatively decrease postoperative morbidity. In this study, a transfusion of PRC greater than $6 \mathrm{ml} / \mathrm{kg}$ was a predictor of an increase in postoperative morbidity of MBTS (OR 17,048; IK95\% 6,608-43,984, p <0.001 In this study, a transfusion of PRC greater than $6 \mathrm{ml} / \mathrm{kg}$ was a predictor of an increase in postoperative morbidity (OR 17,048; IK95\% 6,608-43,984, p <0.001). This is associated with the risk of transmission of infection through blood products. In the study by Dorneles et al, transfusion in patients after heart surgery was known to be associated with an increased risk of mortality by $77 \%$ and an infection risk of $76 \%$. This complication is associated with the incidence of transfusion reactions and transmission of infection. ${ }^{(11)}$

Preoperative use of mechanical ventilation increased morbidity by 8.5 times (OR 8,554; IK95\% 2,476$29,548 ; \mathrm{p}<0.001)$. In bivariate analysis, the use of mechanical ventilation increases the length of ICU care over 48 hours by 1.8 times (OR 1.878, IK95\% $1,610-2,189, \mathrm{p}<0.001)$. The mechanism involved is that the use of mechanical ventilation will increase the pulmonary circulatory resistance so that in this group of patients it will be more difficult to regulate the ratio of pulmonary and systemic blood circulation.(6) The Use of prostaglandin E1 would increase postoperative morbidity of MBTS by 6.2 times (OR 6.273; IK95\% $2.084-18,881 ; \mathrm{p}=0.001)$. This is due to an increase in pulmonary vascular resistance and increased long-term complications in long-term use or sudden termination of Prostaglandin E1. Increased pulmonary vascular resistance will increase the occlusion occurrence due to stasis in the MBTS graft. ${ }^{(7)}$

Our study has a number of limitations, including a retrospective design and the voluntary nature of database, which limit the thorough capture of all relevant data. It is possible that some data might be underreported, such as PDA and MAPCAs ligation at the time of the MBTS procedure. The surgeries were performed by multiple surgeons, and therefore significant differences in operation techniques and hemostatic techniques may have have been present. 
In summary, There is a difference in postoperative mortality and postoperative morbidity based on age criteria. Our study also demonstrates the continued significant risk of death in patients with low weight. Predictors of postoperative morbidity of MBTS include PRC transfusion over $6 \mathrm{ml} / \mathrm{kg}$, use of preoperative mechanical ventilation, and aPTT levels $<60$ seconds after 4 hours postoperatively.

\section{Study Limitation}

We would like to acknowledge that difference in pathogenesis and course of conditions might arise from variations of cardiac malformations that are included in this study. Also we did not have any data regarding history of prematurity or any pregnancy insult that might contribute to these malformations

\section{Conclusion}

Operative mortality rate significantly different among age criteria but it was not proven as an operative mortality predictors.

\section{Conflict Of Interest}

None

\section{Publication Agreement}

The authors of this article give permission to Indonesian Journal of Cardiology to publish this article if this article is accepted

\section{Funding}

Self funded

\section{List of Abbreviations}

aPTT: activated partial thromboplastine time level AoX: aortic cross clamp

PDA: patent ductus arteriosus

PRC: Packed red cell transfusion

MAPCAs: major aortopulmonary collateral arteries MBTS: modified Blalock-Taussig shunt NCCHK: National Cardiovascular Center Harapan Kita

\section{Reference}

1. Alsoufi B, Gillespie S, Mori M, Clabby M, Kanter K, Kogon B. Factors affecting death and progression towards next stage following modified BlalockTaussig shunt in neonates. European Journal Cardio-thoracic Surgery. 2016;50(1):169-77.

2. Dave HH. Modified Blalock-Taussig shunt: Simple but unpredictable. European Journal Cardiothoracic Surgery. 2016;50(1):178-9.

3. Bove T, Vandekerckhove K, Panzer J, de Groote K, de Wolf D, François K. Disease-Specific Outcome Analysis of Palliation With the Modified BlalockTaussig Shunt. World Journal Pediatric Congenital Heart Surgery. 2015;6(1):67-74.

4. Hoffman JIE. The global burden of congenital heart disease : review article. Cardiovascular Journal African. 2013;24(4):141-5.

5. Singh S, Chauhan S, Choudhury M, Malik V, Hote M, Devagourou V, et al. Modified Blalock Taussig shunt: Comparison between neonates, infants and older children. Annals Cardiac Anaesthesia. 2014;17(3):191-8.

6. Petrucci O, O’Brien SM, Jacobs ML, Jacobs JP, Manning PB, Eghtesady P. Risk factors for mortality and morbidity after the neonatal BlalockTaussig shunt procedure. Annals Thoracic Surgery. 2011;92(2):642-52.

7. Hobbes B, d'Udekem Y, Zannino D, Konstantinov IE, Brizard C, Brink J. Determinants of Adverse Outcomes After Systemic-To-Pulmonary Shunts in Biventricular Circulation. Annals Thoracic Surgery. 2017;104(4):1365-70.

8. Park MK. Pathophysiology of Cyanotic Congenital heart disease. In: Park MK, Park's Pediatric Cardiology For Practitioners 6th edition. Philadelphia: Elsevier Saunder;2014

9. Kiran U, Aggarwal S, Choudhary A, Uma B, Kapoor PM. The Blalock and Taussig Shunt Revisited. Annals Cardiac Anaesthesia. 2017;20(4):395-8.

10. Küçük M, Özdemir R, Karaçelik M, Doksöz Ö, Karadeniz C, Yozgat Y, et al. Risk factors for thrombosis, overshunting and death in infants after modified blalock-Taussig shunt. Acta Cardiology Sin. 2016;32(3):337-42.

11. Dorneles CDC, Bodanese LC, Guaragna JCVDC, Macagnan FE, Coelho JC, Borges AP, et al. The impact of blood transfusion on morbidity and mortality after cardiac surgery. Rev Bras Cir Cardiovascular. 2011;26(2):222-9. 